\title{
Dietary lipid level, hepatic lipogenesis and flesh quality in turbot (Psetta maxima)
}

 \\ 1 Fish Nutrition Laboratory, Unité mixte INRA-IFREMER, Centre de Brest IFREMER, 29280 Plouzané, France \\ 2 VP/GA, IFREMER, 44000 Nantes, France \\ 3 LEIMA, INRA, 44316 Nantes, France \\ 4 Fish Nutrition Laboratory, Unité mixte INRA-IFREMER, Lab. de Nutrition des Poissons, Station d'Hydrobiologie, \\ BP 3, 64310 Saint Pée-sur-Nivelle, France \\ *: Corresponding author : kaushik@st-pee.inra.fr, Tel.: +33-5-59-51-59-51; fax: +33-5-59-54-51-52
}

\begin{abstract}
:
A study was undertaken with marketable size turbot to evaluate the effects of dietary fat levels on chemical composition, lipogenesis and flesh quality. Four experimental diets containing graded levels of fish oil in order to obtain $10 \%, 15 \%, 20 \%$ and $25 \%$ of crude fat were fed to triplicate groups of turbot (initial body weight of $660 \mathrm{~g}$ ) for 12 weeks in full strength seawater at temperature of $17^{\circ} \mathrm{C}$. Nutrient digestibility was not influenced by dietary fat levels. The best growth performance was observed in fish fed $10 \%$ and $15 \%$ dietary fat. High dietary lipid levels led to higher fat deposition in whole fish, although lipid level in muscle remained low $(1.1 \%$ in dorsal muscle and $1.7 \%$ in ventral muscle irrespective of diet). Significant subcutaneous fat accumulation was detected in turbot. No protein sparing effect by lipid was observed in turbot fed high dietary fat. Hepatic lipogenic enzymes (glucose6-phosphate dehydrogenase, G6PD; malic enzyme, ME and acetyl CoA carboxylase) did not show any clear change in activity in response to dietary fat content. With regards to quality parameters, there were no differences in gutted and fillet yields among treatments. Sensory analyses of dorsal fillets indicated only a difference in exudation (corresponding to loss of water) and whiteness within treatments in accordance with instrumental colour analyses and on ventral fillets, only a difference of sweet flavour was observed. No differences in hardness were detected by either instrumental texture analysis or sensory analysis. In conclusion, although high dietary lipid levels affected growth and whole body composition of turbot adversely they induced very few alterations in flesh quality.
\end{abstract}




\section{INTRODUCTION}

Fish lipids are rich in n-3 polyunsaturated fatty acids (PUFA) which are essential for fish health and growth. In comparison with terrestrial animal meat, lipids of fish flesh are recognised as beneficial to human health by decreasing cardiovascular and inflammatory disorders (Piclet, 1987; Nettleton, 1991; Klor et al. 1997). In fish nutrition, lipids as a nonprotein energy source allows protein sparing by effectively reducing organic matter and nitrogen losses (Lee and Putnam, 1973) and salmonid aquaculture today uses high fat diets. There is however concern that high level of dietary lipids may lead to increased fat deposition in fish, depending upon species and age, and modifies flesh quality in terms of storage stability, transformation yield and organoleptic and physical properties (Austreng and Krogdahl, 1987; Fauconneau et al., 1993; Guillaume et al., 1996; Gjedrem, 1997; Lie, 1997). A number of studies with salmonids have shown that nutritional factors such as dietary protein sources (Kaushik et al., 1995), fat sources (Guillou et al., 1995), dietary fat content (Bjerkeng et al., 1997), vitamin E (Boggio et al., 1985) and starvation (Einen and Thomassen., 1998; Einen et al., 1998) can influence the physical and organoleptic flesh quality. Some studies in marine flat fish such as Atlantic halibut have also shown the importance of dietary fat levels in modifying flesh quality (Berge and Storebakken, 1991; Nortvedt and Tuene, 1998).

Turbot is a highly valued marine flatfish farmed in northern waters in Europe especially along the Atlantic coast and appreciated by consumers. Turbot is known to have high dietary protein requirements and in juvenile turbot high levels of dietary lipids appear to have adverse effects on growth and body composition (Cacerez-Martinez et al., 1984; Danielssen and Hjertnes, 1993). In some species such as the salmonids, fat deposition is mainly in the viscera and to a 
lesser extent in the muscle. In species such as the European seabass, fats accumulate in liver and viscera (Corraze and Kaushik, 1999). In turbot, lipid accumulation is localised in the marginal body parts (Andersen and Alsted, 1993) with little or no fat deposition in the viscera. The few studies which have dealt with flesh quality in turbot involved some descriptive methodological aspects of volatile compounds on aroma (Prost et al., 1998) and on methods of cooking fillets of Greenland turbot (Maidera and Penfield, 1985).

In terms of the lipogenic process, fish are recognised as comparable to mammals (Iritani et al., 1984). High fat diets depress the activities of several lipogenic enzymes such as fatty acid synthetase, malic enzyme and glucose-6-phosphate dehydrogenase in salmonids (Lin et al., 1977a; Arnesen et al., 1993; Alvarez et al., 1998) and in marine fish like seabass (Bautista et al., 1988; Dias et al., 1998). Little in known about the relation between nutrition and lipogenesis in turbot.

The aim of this study was to evaluate in marketable size turbot the effects of dietary fat levels on nutrient utilisation, tissue composition, fat deposition, lipogenesis, sensory and physical quality of flesh.

\section{MATERIAL AND METHODS}

\section{Experimental diets.}

Four isonitrogenous (digestible protein : 59\%, calculated from apparent digestibility coefficients (ADC) of protein) diets were formulated to contain 10, 15, 20 and 25\% of crude fat, using gradient increases in fish oil. Yttrium oxide (0.1\%) was added as an indicator for digestibility measurements. Diets were manufactured industrially by Nutreco (Aquaculture research Centre, Stavanger, Norway), using a twin-screw extruder, in the form of 9-mm diameter pellets. Ingredient and chemical composition of the diets are reported in Table 1. 


\section{Digestibility measurements.}

Apparent digestibility coefficients (ADC) of the experimental diets were determined with triplicate groups of fish. Fifteen turbot (body weight : 815 \pm 8 g; mean \pm sd) were allotted to cylindroconical tanks, each of which was equipped with a flat-bottomed large-mesh basket and was supplied with fresh seawater (temperature maintained at $17 \pm 1^{\circ} \mathrm{C}$; mean $\pm \mathrm{sd}$ ) in a flow-through system. Fish were fed to satiety once a day and faecal samples were collected using a faeces settling column similar to the one developed by Cho et al. (1982). For each treatment, faecal samples were collected once a day each morning over 2 consecutive weeks and were centrifuged $\left(3000 \mathrm{~g}\right.$ at $6^{\circ} \mathrm{C}$ for $\left.20 \mathrm{~min}\right)$ and kept frozen at $-20^{\circ} \mathrm{C}$. After freeze-drying, the faeces were analysed for yttrium, crude protein, crude fat and gross energy. The ADC of the experimental diets was calculated as follows :

$$
\operatorname{ADC}(\%)=100-\left(100 \frac{\% \text { Tracer in Diet }}{\% \text { Tracer in Faeces }} \times \frac{\% \text { Nutrient or Energy in Faeces }}{\% \text { Nutrient or Energy in Diet }}\right)
$$

\section{Growth study.}

The growth trials were conducted in the experimental facilities of IFREMER (Centre de Brest) at a constant seawater temperature of $17 \pm 0.5^{\circ} \mathrm{C}$ with a salinity of $35 \%$ in a flow through system for a period of 12 weeks. Twenty-two turbot, Psetta maxima, (initial body weight : $657 \pm 6 \mathrm{~g}$; mean $\pm \mathrm{sd})$ were randomly allotted to each tank, $\left(1 \mathrm{~m}^{3}\right.$ tank with a water flow rate of $18 \mathrm{l} \cdot \mathrm{min}^{-1}$ ). A 12/12h light/dark cycle was adopted. The different diets were randomly allotted and triplicate groups were fed by hand once a day to visual satiety (visual observation of first feed refusal) over a 90 min period and feed intake was recorded. Each group was weighed every 3 weeks to follow growth and feed utilisation. 


\section{Samplings.}

At the beginning of the growth study, six fish from an initial pool of fish were sampled and stored at $-20^{\circ} \mathrm{C}$ for analyses of whole body composition. Six fish from the same initial pool were also withdrawn to weigh the liver and the digestive tract for calculating hepatosomatic index (HSI) and viscerosomatic index (VSI).

At the end of the trial, the same protocol of slaughter was followed for each tank. Five fish per tank were withdrawn for comparative carcass analyses (water, ash, protein, fat and energy) and nutrient retention calculation. Blood samples $(1 \mathrm{ml})$ were withdrawn from the best replicate using heparinised syringes. After centrifugation $\left(1200 \mathrm{~g}, 10 \mathrm{~min}, 5^{\circ} \mathrm{C}\right.$ ), plasma was separated and stored frozen at $-20^{\circ} \mathrm{C}$ as separate aliquots for analyses of triglyceride and

total cholesterol concentrations. Six livers and viscera were withdrawn from fish from the same replicate for analyses of lipid and hepatic enzyme activities (glucose-6-phosphate dehydrogenase, acetyl Co-enzyme A carboxylase and malic enzyme). Enzyme activities were measured in fresh liver samples. For quality analyses, fish were stunned, bled to death in ice cold water before dissection. After slaughter, gutting was done immediately and filleting was over within 30 min. Eight fish per tank were withdrawn to weigh the liver and the digestive tract for calculating HSI and VSI and for the following analyses : three fish (fillets with skin) for sensory analyses, three other fish for instrumental analyses of texture (fillets within skin) and finally two fish were withdrawn for lipid analyses in muscle (dorsal and ventral fillets) and skins. Samples of muscle and organs for lipid analyses were frozen in liquid nitrogen and stored at $-80^{\circ} \mathrm{C}$.

\section{Analytical methods.}

The fish for whole boby composition were ground frozen and a representative part was freeze-dried before analysis. Proximate composition analyses of diets, faeces and chemical 
composition of whole body and tissues were conducted following standard laboratory procedures (AOAC, 1984) : dry matter after desiccation in an oven $\left(105^{\circ} \mathrm{C}\right.$ for $\left.24 \mathrm{~h}\right)$, ash (incineration at $550^{\circ} \mathrm{C}$ for $\left.12 \mathrm{~h}\right)$, crude protein $(\mathrm{N} \times 6.25$ using a Dumas nitrogen analyser, Fisons instrument), crude fat (dichloromethane extraction by Soxhlet method) and gross energy (IKA Adiabatic Calorimeter C4000A). Plasma total cholesterol and triglyceride concentrations were determined using commercial kits (Boehringer n¹442341, Mannheim, Germany and bioMérieux $\mathrm{n}^{\circ} \mathrm{PAP} 150$, France, respectively). Analysis of yttrium in the diets and faecal matter was done in pre-digested samples as detailed in Mambrini et al. (1999).

In liver, viscera, muscle and skin samples, total lipid was determined according to Folch et al. (1957), chloroform being replaced by dichloromethane. The separation of neutral lipids and phospholipids were realised according to the procedure described by Juaneda and Rocquelin (1985). The total lipid extracts were fractionated on silica cartridges (Sep-Pack, Waters), neutral lipids were eluted by chloroform and phospholipids by methanol.

For assays of hepatic lipogenic enzyme activities, liver samples were homogenised in three volumes of ice-cold buffer $(0.02 \mathrm{M}$ Tris- $\mathrm{HCl}, 0.25 \mathrm{M}$ sucrose, 2mM EDTA, 0.1M sodium fluoride, 0.5mM phenyl methyl sulphonyl fluoride, 0.01M $\beta$-mercaptoethanol, $\mathrm{pH}$ 7.4) and the homogenates were centrifuged at $20000 \mathrm{~g}$ at $4^{\circ} \mathrm{C}$ for $20 \mathrm{~min}$. Soluble protein content of liver homogenates was determined by the method of Bradford (1976) using bovine serum albumin as the standard. Selected lipogenic enzyme activities were assayed on supernatant fractions : glucose-6-phosphate dehydrogenase (G6PD; EC 1.1.1.49) according to Bautista et al. (1988), malic enzyme (ME; EC 1.1.1.40) according to Ochoa (1955) and acetyl Coenzyme-A carboxylase (AcoAC; EC 6.4.1.2) as per Holland et al. (1984). Enzyme activity units (IU) defined as $\mu$ mol substrate converted to product per min at assay temperature $\left(30^{\circ} \mathrm{C}\right)$, were expressed per mg hepatic soluble protein and per g liver tissue (wet weight). 
Flesh quality evaluation.

Sensory profiling (Stone et al., 1974; ISO 11035) was performed on cooked fillets by an internal sensory panel (IFREMER, Nantes) consisting of 20 individuals selected for their interest, availability and sensorial capacities of memorising stimuli or discriminating intensities. All were volunteers and received regular training sessions to develop their sensory performances and knowledge of marine products. Sessions were conducted in an airconditioned room designed for sensory analysis divided into ten individual boxes with standardized light $\left(\mathrm{T}=6500^{\circ} \mathrm{K}\right)$ and equipped with a computerised system (Fizz, Biosystèmes, Dijon). These conditions were conducive to concentration and avoided communication between assessors and disturbance by external factors (AFNOR V-09-105, 1995). The samples with skin were cooked for 2.5 min in a microwave oven (Panasonic NN8550, 850W) in closed bowl before analyses. Products were assigned 3-digit numbers, randomised and served simultaneously. The samples were evaluated using a continuous scale presented on a computer screen from 0 (low intensity) to 10 (high intensity) for the following attributes : intensity, “potatoes ”, fat fish, marine-iodine and milky for odour; white colour and fatness for visual aspect; intensity, fatty fish, marine, sweet, acid flavour and bitter aftertaste for flavour; and hardness, elasticity, moisture, fat, exudation and sticky for texture in mouth (see Table 9). The odour attributes were assessed immediately after opening the bowl, while flavour and texture in mouth were evaluated after cutting the samples. The data were immediately transferred by the network to a central computer for statistical processing.

Instrumental colour and texture analysis were performed 7 days after slaughter, on fillets kept in ice in sealed vacuum packing and were done on raw and cooked fillets $\left(60 \mathrm{~min}\right.$ at $70^{\circ} \mathrm{C}$ in vacuum packing). For texture, a Kramer shear press $(64 \mathrm{~mm} \times 64 \mathrm{~mm})$ was used with 
compression up to breaking using a universal testing machine (INSTRON, model 4501) with a load cell of $5 \mathrm{kN}$ and during this test, a constant speed of $1 \mathrm{~mm} / \mathrm{s}$ into the fillets was adopted. Samples were withdrawn from the caudal part of fish and measured $64 \mathrm{~mm}$ long and fillet size in width. The weight of each Kramer sample was recorded to avoid possible size differences (Szczesniack et al., 1970). Instrumental colour analysis of raw or cooked fillets was made on the internal part of the fillet with a chromameter (Micro-Color, Dr Lange) using light source D65 and $10^{\circ}$ observer angle. Five measurements per fish were made directely on the fillets behind the head to the tail. Data were expressed as $\mathrm{L}^{*} \mathrm{a}^{*} \mathrm{~b}^{*}$ system, representing lightness, redness and yellowness respectively, recommended by CIE (1976). The $\mathrm{pH}$ of fillets was measured using a $\mathrm{pH}$ meter Metrohm on internal part of fillet. The instrumental analyses followed procedures described by Laroche et al. (1996).

\section{Statistical analysis}

All data except sensory analysis were subjected to one-way analysis of variance to test the effects of experimental diets. In cases where significant differences occurred (significance level $=0.05$ ), the means were compared using Newman-Keuls test. The statistical tests (ANOVA and regression) were performed using the STAT-ITCF (1988) software. The results of sensory analyses were subjected to two-way analysis of variance to test the effects of experimental diets and assessors. In cases where significant differences occurred, the means were compared using Duncan test with the FIZZ, Biosystèmes software. 


\section{RESULTS}

Nutrient and energy digestibility.

The apparent digestibility coefficients (ADC) of protein was above 95\% for all diets, with a low but significant difference between diets (Table 2). ADC of fat was not affected by dietary treatment $(\mathrm{P}>0.05)$ but ADC of energy was significantly higher for diets with 15 and 25\% lipid than for the low-fat diet. The digestible protein to digestible energy (DP/DE) ratios of the four experimental diets decreased from 30.8 to $26.5 \mathrm{mg}$ of DP / kJ of DE (Table 1).

\section{Growth performance}

There was a decrease in growth with the increase in dietary fat level (Table 3). Fish fed the diet containing $10 \%$ lipid had the highest growth performance $(\mathrm{P}<0.05)$, significantly higher than those fed diets containing 20 and $25 \%$ lipid. Although there was no difference $(\mathrm{P}>0.05)$ between groups for feed efficiency (FE) or protein efficiency ratio (PER), the highest values were observed in turbot fed diets with 10 and 15\% lipid.

Whole body and tissue composition and retention.

No significant difference was found in whole body moisture, ash and protein content of fish fed the different fat levels (Table 4). Whole body fat content increased significantly from 3.0 to $4.8 \%$ when fish were fed diets containing 10 and 25\% lipid. HSI and VSI did not vary significantly $(\mathrm{P}>0.05)$ among treatments and were similar to values of the initial fish. Viscera only represented between 2.5 to $2.7 \%$ of body weight.

Protein and energy retention (as \% of intake) were lightly affected by the increase in dietary fat level. Protein retention was the highest in fish fed the low-fat diet. Likewise, daily $\mathrm{N}$ gain (Fig. 1) of turbot tended to decrease with increasing dietary fat levels although without any 
significant difference $(\mathrm{P}>0.05)$ between treatments. Lipid gain was high in fish fed the diet containing 25\% lipid. In fish fed the low-fat diet, practically no fat deposition was observed.

Dry matter and fat contents of liver were significantly higher in turbot fed the $20 \%$ lipid diet than in those fed diets containing 10 and 25\% lipid (Table 5). Hepatic fat content varied between 12 to $21 \%$ of wet weight and was significantly higher in fish fed the $20 \%$ lipid diet than in the other groups. Visceral fat content varied between 1.6\% (fish fed the diet with 20\% lipid) to $2.2 \%$ (fish fed the diet with $25 \%$ lipid). Dorsal and ventral muscle fat contents were not affected by diets $(\mathrm{P}>0.05)$. Ventral muscle appeared in general to contain more fat $(1.7 \%)$ than dorsal muscle (1.1\%). The values of skin fat content varied between 3.3 to $4.7 \%$ of fresh weight, however with no significant effect $(\mathrm{P}>0.05)$ of dietary fat levels.

\section{Plasma cholesterol and triglyceride concentrations.}

Plasma total cholesterol and triglyceride concentrations are reported in Fig. 2. Both plasma cholesterol and triglyceride concentrations increased with increasing dietary fat levels. However, only cholesterol concentrations showed a significant difference among the dietary treatment $(\mathrm{P}<0.05)$, turbot fed the high lipid diet showing significantly higher values than those found for the other groups.

\section{Activities of lipogenic enzymes.}

Data on the activities of the lipogenic enzymes assayed in turbot liver are reported as IU or mIU of g liver and per mg protein (Table 6). Acetyl-CoenzymeA carboxylase and malic enzyme had low activities and were not affected by dietary treatment. Only the activities of G6PD showed significant differences with G6DPH activities in fish fed the 15\% lipid diet being significantly higher than those in turbot fed the low fat diet $(\mathrm{P}<0.05)$. 
Flesh quality.

Sensory analyses were realised on ventral and dorsal fillets and the assessors did not find any difference between the dorsal and ventral fillets. On dorsal fillets, visual aspects of white colour appeared higher for groups fed diets rich in lipids than in flesh from fish fed diets low in lipids (Table 7). Fillets from fish fed diets containing 10 and 15\% lipid appeared significantly less white than fillets of fish fed diets containing 20 and 25\% lipid. For texture in mouth, exudation (corresponding to a loss of water of the fillet) was significantly reduced in groups fed the 20 and 25\% lipid diets. For other attributes, no effect of dietary treatments was observed on dorsal fillets. On ventral fillets, no significant effect of dietary fat levels was observed except for sweet flavour : fillets from fish fed the 10 and $20 \%$ lipid diets were statistically less sweet than fillets from groups fed diets containing 15 and 25\% lipid (Table 8). Intensity of flavour appeared more pronounced in fillets of turbot fed the 15 and $20 \%$ lipid diets and hardness of texture in mouth was lower in fillets of turbot fed the low-fat diet.

Gutted yield in turbot was very high and fillet yield was low $(<30 \%)$ with no significant differences among treatments (Table 9). On raw fillets, $\mathrm{pH}$ values were not affected by dietary treatment; however on cooked fillets, $\mathrm{pH}$ values of fish fed the $20 \%$ lipid diet were significantly lower than those of the other groups $(\mathrm{P}<0.05)$. Concerning colour analyses, $\mathrm{L}^{*}$ (lightness) values were significantly influenced by dietary fat levels on raw and cooked fillets. On cooked fillets, b* (yellowness) values were significantly higher for fish fed diets rich in lipid. No significant effect of dietary fat levels was observed for any of the parameters of instrumental texture analyses on raw or cooked fillets (Table 9).

\section{DISCUSSION}


Given that high quality protein sources were used, protein digestibility was high (above 95\%) and comparable to values generally found in other teleosts (Cho and Kaushik, 1990; NRC, 1993). The decantation method was chosen instead of the continuous screen collector (Choubert et al., 1982) since preliminary trials had shown that faecal matter from turbot had a tendency to stick to the mesh screens. Nutrient leaching was reduced by the addition of binder in the diets and the losses in the supernatant after centrifugation were unimportant. Using the same method in European seabass, the nitrogen leaching was found to be insignificant (Spyridakis et al., 1989).

Data on growth performance of turbot of this size ( $>650 \mathrm{~g})$ are comparable to summary data provided by Nijhof (1991) for turbot of similar body weight range. The decline in growth rate with increasing fat levels has already been observed by Cacerez-Martinez (1984) in juvenile turbot (weighing 10g), fed diets with fat levels ranging from 10 to $20 \%$. But, Danielssen and Alsted (1993) reported no adverse effect of fat levels of upto $22 \%$ on growth of juvenile turbot. In Atlantic halibut, Berge and Storebakken (1991) did not observe any effect of dietary fat on body weight gain when dietary fat content increased from 8 to $20 \%$. Contrary to many other species like salmonids or seabass where a protein sparing has been well demonstrated (Lee and Putnam, 1973; Watanabe, 1982; Beamish and Medland, 1986; Cho and Kaushik, 1990; Arzel et al., 1994; Dias et al., 1998), an increase in dietary lipid levels does not appear to improve protein utilisation in turbot with no clear protein sparing effect of dietary fat. In Atlantic halibut, another flatfish, Aksnes et al. (1996) however found a protein sparing effect with an increase on dietary lipid, but the diets were not isonitrogenous. In the present study with the same protein retention, fish fed the $25 \%$ lipid diet had a higher fat gain than fish fed the $20 \%$ lipid diet possibly causing the difference in weight gain. 
Turbot appear to generally have a low whole body fat content $(<5 \%)$, in agreement with the data of Sheehan et al. (1994). An increase in dietary lipid level however led to increased whole body lipid content in turbot, as reported also by Andersen and Alsted (1993) when dietary fat levels increased from 13 to $32 \%$. Such effects are in agreement with data from other salmonids (Arzel et al., 1994; Hillestad and Johnsen, 1994; Alvarez et al., 1998) or other marine teleosts such as seabass (Alliot et al., 1979; Peres and Oliva-Teles, 1999), gilthead sea bream (Vergara et al., 1996; Vergara et al., 1999) or Atlantic halibut (Aksnes et al., 1996). Total liver lipid content ranged from 12 to $21 \%$ of fresh liver weight in this present study which was relatively low in comparison with seabass or high in comparison with salmonids (Corraze and Kaushik, 1999). The accumulation of fat in the liver of turbot fed the $20 \%$ lipid diet and the relatively poor growth of these fish is difficult to explain and needs further analysis.

Muscle fat content in turbot was very low (near 1\%) and comparable to data of Sérot et al. (1998) in farmed turbot of $1 \mathrm{~kg}$. The latter study reported that compared to wild fish of similar body weight, cultured fish muscle contain more fat (1.1 versus $0.6 \%)$. In this present study, skin fat content was around $4 \%$ of wet weight, showing that turbot accumulate a part of the fat under the skin. The weight of liver, viscera, muscle and skin only represented about $40 \%$ of body weight. If the values of previous tissue fat content (C.f. Table 5) were reported in terms of body weight, this study showed that turbot accumulated a significant amount (estimated around 2/3) of fat in the rest of carcass (bones, fins, head,...).

Tissue cholesterol concentrations are known to vary depending upon the nutritional status of fish (Fremont and Leger, 1981; Kennish et al. 1992; Kaushik et al. 1995). Plasma cholesterol concentrations observed here increased with an increase of dietary fat and were low compared to other species (Alexis et al., 1985; Kaushik et al., 1995), but higher than those observed in juvenile turbot fed a fish meal diet in a previous study (Regost et al., 1999). 
The preferential site of de novo fatty acid synthesis in fish is the hepatic tissue (Lin et al., 1977a, b; Sargent et al., 1989). With respect to the two NADPH-generating enzymes, the activity of G6PD was nearly 10 times higher than that of ME in turbot, in accordance with data from other finfish (Iritani et al., 1984; Bautista et al., 1988; Dias et al., 1998). The activities of G6PD, ME and ACoAC observed in the present study were lower than those reported for rainbow trout and seabass (Alvarez et al., 1998; Dias et al., 1998). In most teleosts studied to date, G6PD, ME and fatty acid synthetase activities decrease with an increase in dietary lipid level and a concurrent decrease in dietary carbohydrate (Likimani and Wilson, 1982; Arnesen et al., 1993; Shimeno et al., 1995; Alvarez et al., 1998; Dias et al., 1998). The absence of any change in hepatic lipogenic enzymes studied here possibly reflect the high protein requirements, low lipid deposition and the relative absence of response to high dietary lipids of turbot. In rats, it is known that even a slight increase (in the order of 3\%) in dietary fat reduces the activity of these enzymes (Kelley et al., 1987), whereas in other teleosts, such a reduction occurs only with large changes in dietary fat content (Dias et al., 1998). Turbot apparently differs significantly in this regard. It might be worth verifying whether juvenile cultivated turbot or wild turbot have similar activity levels and if the low response of lipogenic enzymes truly reflects the metabolic specificities of this species or due to a size-related low growth rates in big fish. In rainbow trout, Walzem et al. (1991) have indeed shown that liver enzyme activities were correlated with food intake and growth.

Relatively few studies have dealt with flesh quality in turbot farmed under controlled conditions. One of the striking features, despite a high gutted yield, was the poor fillet yield $(<30 \%)$ in turbot of this size compared to salmonids where it is not uncommon to have yields above 50\% (Einen et al., 1998). Aksnes et al. (1996) in Atlantic halibut found that high dietary lipid level (13 to 32\%) affected slaughter quality increasing the entrails index and 
decreasing the slaughter yield. Such a change was not found in turbot where visceral fat depositions were low. In fact, viscerosomatic index were also low in turbot compared to other teleosts (Fauconneau, 1988; Oliva-Teles et al., 1994; Ballestrazzi et al., 1994; Dias et al., 1998). The relatively low (near 1\%) hepatosomatic index in turbot found here has been reported earlier in turbot (Cacerez-Martinez, 1984) and in Atlantic halibut (Aknes et al. 1996; Helland and Grisdale-Helland, 1998). These values are much lower than those (around 2,3\%) reported for other marine species such as European seabass (Ballestrazzi et al., 1994; Dias et al., 1998) or red sea bream (Takeuchi et al., 1991). Sensory attributes of turbot were not affected by dietary fat level except whiteness; this was also confirmed by instrumental colour analysis. There was also no relation between sensory descriptors of fat and muscle fat level probably due to the low fat content in turbot muscle. The methods to cook fillets were different in sensory analyses (microwave) and in instrumental analyses (double boiler). According to Madeira and Penfield (1985), no difference in acceptability of Greenland turbot heated by two cooking methods (conventional oven and microwave oven) was observed. The values obtained in instrumental texture analyses in turbot showed that texture of turbot fillet was firm in comparison to salmonids (Laroche et al., 1996). Given the scarcity of data from the literature, it is difficult to draw generalised conclusions in this regard.

In conclusion, this present study under controlled conditions with a wide range of dietary fat levels confirms that high dietary lipid levels (above 15\%) do not bring about any clear protein sparing effect in turbot. Fat deposition in turbot was localised under the skin and in the carcass. The low hepatic lipogenic activities and poor fat utilisation in turbot needs further investigation. Given that diets for turbot are rich in protein and that they do not seen to benefit from dietary lipid, it would be worth investigating how far dietary protein levels or carbohydrates can affect changes in lipid metabolism. 


\section{ACKNOWLEDGEMENTS}

This study was supported by the project with the NUTRECO ARC (Stavanger, Norway). The authors would like to express their gratitude to Hervé Le Delliou for his technical assistance for proximate analysis. C. Regost is a recipient of a partial financial scholarship from Région Bretagne.

\section{REFERENCES}

AFNOR, 1995. Directives générales pour l'implantation de locaux destinés à l'analyse sensorielle (NF V 09-105). In : Contrôle de la qualité des produits alimentaires, analyse sensorielle, 5ème édition AFNOR, Paris La Défense, 115-127.

AOAC (Association of Official Analytical Chemists) 1984. Official Methods of Analysis. 12th edition, Association of Official Analytical Chemists, Washington DC, USA, 1141p.

Aksnes, A., Hjertnes, T., Opstvedt, J., 1996. Effect of dietary protein level on growth and carcass composition in Atlantic halibut (Hippoglossus hippoglossus L.). Aquaculture $145,225-233$.

Alexis, M.N., Papaparaskev-Papoutsoglou, E., Theochari, V., 1985. Formulation of practical diets for rainbow trout (Salmo gairdneri) made by partial or complete substitution of fish meal by poultry by-products and certain plant by-products. Aquaculture 50, 61-73.

Alliot, E., Pastoureaud, A., Nedellec, J., 1979. Etude de l'apport calorique et du rapport calorico-azoté dans l'alimentation du bar Dicentrarchus labrax. Influence sur la croissance et la composition corporelle. In: Halver J.E. and Tiews K. (Eds.), Proc. World 
Symp. on Finfish Nutrition and Fishfeed Technology, Hamburg, Germany, vol I. Heenemann, Berlin, 241-255.

Alvarez, M.J., Lopez-Bote, C.J., Diez, A., Corraze, G., Arzel, J., Dias, J., Kaushik, S.J., Bautista, J.M., 1998. Dietary fish oil and digestible protein modify susceptibility to lipid peroxidation in the muscle of rainbow trout (Oncorhynchus mykiss) and sea bass (Dicentrarchus labrax). Br. J. Nutr. 80, 281-289.

Andersen, N.G., Alsted, N.S., 1993. Growth and body composition of turbot (Scophthalmus maximus) in relation to different lipid/protein ratios in the diet. In : Kaushik S.J., Luquet P. (Eds.) Fish Nutrition in Practice, Biarritz, France, INRA Editions. Les Colloques nº61, 479-491.

Arnesen, P., Krogdahl, A., Kristiansen, I.O., 1993. Lipogenic enzyme activities in liver of Atlantic salmon (Salmo salar). Comp. Biochem. Physiol. 105B, 541-546.

Arzel, J., Martinez Lopez, F.X., Métailler, R., Stéphan, G., Viau, M., Gandemer, G., Guillaume, J., 1994. Effect of dietary lipid on growth performance and body composition of brown trout (Salmo trutta) reared in seawater. Aquaculture 123, 361-375.

Austreng, E., Krogdahl, A., 1987. Food quality of cultured salmonids can be influenced. Feedstuffs 59, 12-14.

Ballestrazzi, R., Lanari, D., D'Agaro, E., Mion, A., 1994. The effect of dietary protein level and source on growth, body composition, total ammonia and reactive phosphate excretion of growing sea bass (Dicentrarchus labrax). Aquaculture 127, 197-206.

Bautista, J.M., Garrido-Pertierra, A., Soler, G., 1988. Glucose-6-phosphate dehydrogenase from Dicentrarchus labrax liver : kinetic mechanism and kinetic of NADPH inhibition. Biochim. Biophys. Acta. 967, 354-363.

Beamish, F.W.H., Medland, T.E., 1986. Protein sparing effects in large rainbow trout, Salmo gairdneri. Aquaculture 55, 35-42. 
Berge, G.M., Storebakken, T., 1991. Effect of dietary fat level on weight gain, digestibility, and fillet composition of Atlantic halibut. Aquaculture 99, 331-338.

Bjerkeng, B., Refstie, S., Fjalestad, K.T., Storebakken, T., Rødbotten, M., Roem, A.J., 1997. Quality parameters of the flesh of Atlantic salmon (Salmo salar) as affected by dietary fat content and full-fat soybean meal as a partial substitute for fish meal in the diet. Aquaculture 157, 297-309.

Boggio, S.M., Hardy, W.H., Babbitt, J.K., Brannon, E.L., 1985. The influence of dietary lipid source and alpha-tocopheryl acetate level on product quality of rainbow trout (Salmo gairdneri). Aquaculture 51, 13-24.

Bradford, M.M., 1976. A rapid and sensitive method for the quantitation of microgram quantities of protein utilizing the principle of proein-dye binding. Anal. Biochem. 72, 48254.

Cacerez-Martinez, C., 1984. Etudes sur les besoins nutritionnels de la sole (Solea vulgaris) et du turbot (Psetta maxima). Thèse de Doctorat, Université de Bretagne Occidentale, Brest, France, 132 pp.

Cacerez-Martinez, C., Cadena-Roa, M., Métailler, R., 1984. Nutritional requirements of turbot (Scophthalmus maximus). I. A preliminary study of protein and lipid utilization. J. World Maricult. Soc. 15, 191-202.

Cho, C.Y., Kaushik, S.J., 1990. Nutritional energetics in fish : Protein and energy utilization in rainbow trout. In: Bourne, G.H. (Ed). Aspects of Food Production, Consumption and Energy Values. World Rev. Anim. Nutr. 61, 132-172.

Cho, C.Y., Slinger, S.J., Bayley H.S., 1982. Bioenergetics of salmonids fishes : energy intake expenditure and productivity. Comp. Biochem. Physiol. 73B, 25-41.

Choubert G., De la Noue, J. , Luquet, P., 1982. Digestibility in fish : improve device for the automatic collection of feces. Aquaculture 29, 185-189. 
Corraze, G., Kaushik, S.J., 1999. Les lipides des poissons marins et d'eau douce. Oléagineux Corps gras Lipides (OCL) 6, 111-115.

Danielssen, D.S., Hjertnes, T., 1993. Effect of dietary protein levels in diets for turbot (Scophthalmus maximus) to market size. In: Kaushik S.J., Luquet P. (Eds.) Fish Nutrition in Practice, Biarritz, France, 24-27/01/1991, INRA Editions. Les Colloques $n^{\circ} 61,89-96$.

Dias, J., Alvarez, M.J., Diez, A., Arzel, J., Corraze, G., Bautista, J.M., Kaushik, S.J., 1998. Regulation of hepatic lipogenesis by dietary protein / energy in juvenile European seabass (Dicentrarchus labrax). Aquaculture 161, 169-186.

Einen, O., Thomassen, M.S., 1998. Starvation prior to slaughter in Atlantic salmon (Salmo salar). II. White muscle composition and evaluation of freshness, texture and colour characteristics in raw and cooked fillets. Aquaculture 169, 37-53.

Einen, O., Waagen B., Thomassen, M.S., 1998. Starvation prior to slaughter in Atlantic salmon (Salmo salar). I. Effects on weight loss, body shape, slaughter and fillet-yield, proximate and fatty acid composition. Aquaculture 166, 85-104.

Fauconneau, B., 1988. Partial substitution of protein by single amino acid or an organic acid in rainbow trout diets. Aquaculture 70, 97-106.

Fauconneau, B, Chmaitilly, J., Andre, S., Cardinal, M., Cornet, J., Vallet, J.L., Dumont, J.P., Laroche, M., 1993. Caractéristiques de la chair de truite arc en ciel. II. Composantes physiques et sensorielles. Sci. Alim. 13, 188-199.

Folch, J., Lees, M., Sloane Stanley, G.H., 1957. A simple method for the isolation and purification of total lipides from animal tisues. J. Biol. Chem. 226, 497-509.

Fremont, L., Léger, C., 1981. Le transport des lipides plasmatiques. In: Fontaine M., (Ed.), Nutrition des Poissons, Editions du Centre National de la Recherche Scientifique, Paris, 263-282. 
Gjedrem, T., 1997. Flesh quality improvment in fish through breeding. Aquacult. Int. 5, 197206.

Guillaume, J., Arzel, J., Stepan, G., Fauconneau, B., 1996. Lipides et qualité de la chair de poisson. In : Gandemer G. (Eds.) Lipides et Qualité des Aliments d’Origine Animale, Journées Chevreul, Nantes, France, 5-6 nov. 1996, 47-59.

Guillou, A., Soucy, P., Khalil, M., Adambounou, L., 1995. Effects of dietary vegetable and marine lipid on growth, muscle fatty acid composition and organoleptic quality of flesh of brook charr (Salvelinus fontinalis). Aquaculture 136, 351-362.

Helland, S.J., Grisdale-Helland, B., 1998. Growth, feed utilization and body composition of juvenile Atlantic halibut (Hippoglossus hippoglossus) fed diets differing in the ratio between the macronutrients. Aquaculture 166, 49-56.

Hillestad, M., Johnsen, F., 1994. High-energy/low protein diets for Atlantic salmon: Effects on growth, nutrient retention and slaughter quality. Aquaculture 124, 109-116.

Holland, R., Witters, L.A., Hardie, D.G., 1984. Glucagon inhibits fatty acid synthetis in isolated hepatocytes via phosphorylation of acetyl CoA carboxylase by cyclic AMPdependent protein kinase. Eur. J. Biochem. 140, 325-333.

Iritani, N., Ikeda, Y., Fukuda, H., Katsurada, A., 1984. Comparative study of lipogenic enzymes in several vertebrates. Lipids 19, 828-835.

ITCF, 1988. STAT-ITCF, 4 ème éd. Service des Etudes Statistiques, Paris, France.

Juaneda, P., Rocquelin, G., 1985. Rapid and convenient separation of phospholipids and non phosphorus lipids from rat heart using silica cartridges. Lipids 20, 40-41.

Kaushik, S.J., Cravedi, J.P., Lalles, J.P., Sumpter, J., Fauconneau, B., Laroche, M., 1995. Partial or total replacement of fish meal by soya protein on growth, protein utilization, potential estrogenic or antigenic effects, cholesterolemia and flesh quality in rainbow trout. Aquaculture 133, 257-274. 
Kelley, D.S., Nelson, G.J., Serrato, C.M., Schimdt., P.C., 1987. Nutritional regulation of hepatic lipogenesis in the rat. Nutr. Res. 7, 509-517.

Kennish, J.M., Sharpdahl, J.L., Chambers, K.A., Thrower, F. and Rice, S.D., 1992. The effect of a herring diet on lipid composition, fatty acid composition, and cholesterol levels in muscle tissue of pen-reared chinook salmon (Oncorhynchus tshawytscha). Aquaculture 108, 309-322 .

Klor, H., Hauenschild, A., Holbach, I., Kretschmer, H., Stroh, S., 1997. Nutrition and cardiovascular disease. Eur. J. Med. Res., 2, 243-257.

Laroche, M., Fauconneau, B., Marcel, J., 1996. Effet de la durée et des conditions de stockage (réfrigération et congélation) sur des caractéristiques de texture de filets de truite fario (Salmo trutta) et de carpe (Cyprinus carpio). In : "Froid et Aquaculture", Comptes rendus Réunion de la Commission C2 de l'Institut International du Froid, Bordeaux, France, 2022 mars 1996, 393-400.

Lee, D.J., Putnam, G.B., 1973. The response of rainbow trout to varying protein/energy ratios in a test diet. J. Nutr. 103, 916-922.

Lie, O., 1997. Fish nutrition and product quality. 16th International Congres of Nutrition, Montreal, Canada, August 1997, 4 pp.

Likimani, T.A., Wilson, R.P., 1982. Effects of diet on lipogenic enzyme activities in channel catfish hepatic and adipose tissue. J. Nutr. 112, 112-117.

Lin, H., Romsos, D.R., Tack, P.I., Leveille, G.A., 1977a. Influence of dietary lipid on lipogenic enzyme activities in coho salmon (Oncorhynchus kisutch). J. Nutr. 107, 846854.

Lin, H., Romsos, D.R., Tack, P.I., Leveille, G.A., 1977b. Effects of fasting and feeding various diets on hepatic lipogenic enzyme activities in coho salmon (Oncorhynchus kisutch). J. Nutr. 107, 1477-1483. 
Madeira, K., Penfield, M.P., 1985. Turbot fillet sections cooked by microwave and conventional heating methods : objective and sensory evaluation. J. Food Sci. 50, 172173.

Mambrini, M., Roem, A., Cravedi, J.P., Lalles, J.P., Kaushik, S.J., 1999. Effects of replacing fishmeal by soy protein concentrate and of DL-methionine supplementation in high energy extruded diets on growth and nutrient utilisation in rainbow trout, Oncorhynchus mykiss. J. Anim. Sci. 77 : 2990-2999

National Research Council (NRC), 1993. Nutrient Requirements of Fish. National Academy Press, Washington, DC, 114 pp.

Nettleton, J.A., 1991. w-3 Fatty acids : comparison of plant and seafood sources in human nutrition. J. Am. Diet. Assoc., 91, 331-337.

Nijhof, M., 1991. Effects of body weight on diet requirements of turbot (Scophthalmus maximus) with special reference to feed intake and body composition. In : Kaushik S.J., Luquet P., (Eds.). Fish Nutrition in Practice, Ed INRA, Les colloques, n61, 501-513.

Nortvedt, R., Tuene, S., 1998. Body composition and sensory assessment of three weight groups of Atlantic halibut (Hippoglossus hippoglossus) fed three pellet sizes and three dietary fat levels. Aquaculture 161, 295-313.

Ochoa, S., 1955. Malic enzyme. In : Collowick, S.P., Kaplan, N.O. (Eds), Methods in Enzymology. Vol. 1. Academic Press, New York, pp 739-753.

Oliva-Teles, A., Gouveia, A.J., Gomes, E. and Rema P., 1994. The effect of different processing treatments on soybean meal utilization by rainbow trout, Oncorhynchus mykiss. Aquaculture 124, 343-349.

Peres, H., Olivia-Teles, A., 1999. Effect of dietary lipid level on growth performance and feed utilisation by European sea bass juveniles (Dicentrarchus labrax). Aquaculture 179, 325334. 
Piclet, G., 1987. Le poisson aliment. Composition-intêret nutritionnel. Cah. Nutr. Diet. XXII, 317-336.

Prost, C., Sérot, T., Demaimay, M., 1998. Identification of the most potent odorants in wild and farmed cooked turbot (Scophtalmus maximus). J. Agric. Food Chem. 46, 3214-3219.

Regost, C., Arzel, J., Kaushik, S.J., 1999. Partial or total replacement of fish meal by corn gluten meal in diets for turbot (Psetta maxima). Aquaculture 180, 99-117.

Sargent, J., Henderson, R.J., Tocher, D.R., 1989. The lipids. In : Halver J.E. (Ed.), Fish Nutrition, Academic Press, Inc. 153-218.

Sérot, T., Gandemer, G., Demaimay, M., 1998. Lipid and fatty acid compositions of muscle from farmed and wild adult turbot. Aquacult. Int. 6, 331-343.

Sheehan, E.M., Sheehy, P.J.A., Morrissey, P.A., Fitzgerald, R., 1994. Compositional analysis on wild and farmed turbot, and fish feeds in Ireland. In : Lavens P., Remmerswaal, R.A.M. (Eds.), Turbot Culture : Problems and Prospects. European Aquaculture Society No. 22, Gent, Belgium, 302-311.

Shimeno, S., Keyyali, D., Shikata, T., 1995. Metabolic response to dietary lipid to protein ratios in common carp. Fisheries Sci. 61, 977-980.

Spyridakis, P., Métailler, R., Gabaudan, J., Riaza, A., 1989. Studies on nutrient digestibility in european sea bass (Dicentrarchus labrax). 1. Methodological aspects concerning faeces collection. Aquaculture 77, 61-70.

Stone, H., Sidel, J.L., Oliver, S., Woolsey, A., Singleton, R.C., 1974. Sensory evaluation by quantitative descriptive analysis. Food Tech. 28 (11), 24-34.

Szczesniack, A.S., Humaugh, P.R., Block, H.W., 1970. Behaviour of different foods in the standard shear compression cell of the shear press and the effect of sample weight on peak area and maximum force. Texture Studies 1, 356-378. 
Takeuchi, T., Shiina, Y. , Watanabe, T., 1991. Suitable protein and lipid levels in diet for fingerlings of red sea bream (Pagrus major). Nippon Suisan Gakkaishi 57, 293-299.

Vergara, J.M., Robaina, L., Izquierdo, M., de la Higuera, M., 1996. Protein sparing effect of lipids in diets for fingerlings of gilthead sea bream. Fisheries Sci. 62, 624-628.

Vergara, J.M., Lopez-Calero, G., Robaina, L., Caballero, M.J., Montero, D., Izquierdo, M.S., Aksnes, A., 1999. Growth, feed utilization and body lipid content of gilthead seabream (Sparus aurata) fed increasing lipid levels and fish meals of different quality. Aquaculture 179, 35-44.

Watanabe, T., 1982. Lipid nutrition in fish. Comp. Biochem. Physiol. 73B: 3-15.

Walzem, R.L., Storrebakken, T., Hung, S.S.O., Hansen, R.J., 1991.Relationship between growth and selected liver enzyme activities of individual rainbow trout. J. Nutr. 121; 1090-1098. 
Table 1 : Ingredients and proximate composition of the experimental diets.

\begin{tabular}{|c|c|c|c|c|}
\hline & \multicolumn{4}{|c|}{ Experimental diets } \\
\hline & 10 & 15 & 20 & 25 \\
\hline \multicolumn{5}{|l|}{ Ingredients (\%) } \\
\hline Fish meal (Norseamink) & 50.0 & 50.0 & 50.0 & 50.0 \\
\hline Soluble fish protein concentrate & 8.0 & 8.0 & 8.0 & 8.0 \\
\hline Whole wheat & 22.1 & 15.3 & 8.3 & 1.5 \\
\hline Wheat gluten & 13.1 & 14.7 & 16.4 & 18.0 \\
\hline Fish oil & 3.8 & 9.0 & 14.3 & 19.5 \\
\hline Mineral mix ${ }^{(1)}$ & 1.0 & 1.0 & 1.0 & 1. 0 \\
\hline Vitamin mix ${ }^{(1)}$ & 1.0 & 1.0 & 1.0 & 1.0 \\
\hline Binder (Edelbind) & 0.9 & 0.9 & 0.9 & 0.9 \\
\hline Yttrium oxide & 0.1 & 0.1 & 0.1 & 0.1 \\
\hline \multicolumn{5}{|l|}{ Proximate composition } \\
\hline Dry matter (DM), \% & 89.8 & 90.1 & 91.0 & 93.6 \\
\hline Crude protein, \% DM & 61.3 & 62.2 & 62.5 & 61.3 \\
\hline Crude fat, \% DM & 11.3 & 16.2 & 21.4 & 27.7 \\
\hline Phospholipids, \% DM ${ }^{(2)}$ & 2.7 & 3.0 & 3.2 & 3.8 \\
\hline Ash, \% DM & 8.5 & 8.2 & 8.1 & 8.3 \\
\hline Gross energy, kJ/gDM & 22.1 & 23.2 & 24.1 & 24.6 \\
\hline Digestible Protein (DP), \% DM ${ }^{(3)}$ & 58.7 & 59.9 & 59.9 & 59.1 \\
\hline Digestible Energy (DE), kJ/gDM & 19.0 & 20.9 & 21.6 & 22.3 \\
\hline $\mathrm{DP} / \mathrm{DE}$ ratio, $\mathrm{mg} / \mathrm{kJ}$ & 30.8 & 28.6 & 27.7 & 26.5 \\
\hline
\end{tabular}

(1) Propreitary mixtures (Nutreco, ARC) providing levels meeting requirements as proposed by NRC (1993)

(2) Levels of phospholipids were calculated from lipids of Folch analyses.

(3) DP and DE values are based on apparent digestibility coefficients (ADC) of protein and energy reported in Table 3. 
Table 2 : Apparent digestibility coefficients (ADC) \% of experimental diets.

\begin{tabular}{lcccc}
\hline \multirow{2}{*}{ ADC (\%) } & \multicolumn{4}{c}{ Experimental diets } \\
\cline { 2 - 5 } & 10 & 15 & 20 & 25 \\
\cline { 2 - 5 } Proteins & $95.8 \pm 0.0^{\mathrm{b}}$ & $96.3 \pm 0.1^{\mathrm{a}}$ & $95.8 \pm 0.1^{\mathrm{b}}$ & $96.4 \pm 0.2^{\mathrm{a}}$ \\
Fat & $94.4 \pm 0.6$ & $95.2 \pm 0.2$ & $93.2 \pm 0.9$ & $93.4 \pm 0.6$ \\
Energy & $86.1 \pm 0.1^{\mathrm{c}}$ & $90.0 \pm 0.4^{\mathrm{ab}}$ & $89.5 \pm 0.1^{\mathrm{b}}$ & $90.6 \pm 0.1^{\mathrm{a}}$ \\
\hline
\end{tabular}

Values are means \pm standard deviations $(\mathrm{n}=3)$. Values in the same row with different superscripts are significantly different $(\mathrm{P}<0.05)$. 
Table 3 : Growth performance, feed efficiency and protein efficiency ratio in turbot fed gradient levels of fat in isonitrogenous diets over 12 weeks at $17^{\circ} \mathrm{C}$.

\begin{tabular}{|c|c|c|c|c|}
\hline & \multicolumn{4}{|c|}{ Experimental diets } \\
\hline & 10 & 15 & 20 & 25 \\
\hline IBW $(g)^{1}$ & $651.5 \pm 7.1$ & $670.7 \pm 13.9$ & $645.2 \pm 18.9$ & $659.5 \pm 10.1$ \\
\hline WG(g) ${ }^{2}$ & $229.1 \pm 10.8^{a}$ & $204.0 \pm 15.6^{\mathrm{ab}}$ & $132.9 \pm 11.6^{\mathrm{C}}$ & $173.6 \pm 5.8^{\mathrm{bc}}$ \\
\hline $\mathrm{SGR}^{3}$ & $0.36 \pm 0.01^{\mathrm{a}}$ & $0.31 \pm 0.03^{\mathrm{ab}}$ & $0.22 \pm 0.02^{\mathrm{b}}$ & $0.28 \pm 0.01^{\mathrm{b}}$ \\
\hline $\mathrm{FE}^{4}$ & $0.99 \pm 0.01$ & $1.00 \pm 0.05$ & $0.83 \pm 0.04$ & $0.97 \pm 0.03$ \\
\hline $\mathrm{PER}^{5}$ & $1.66 \pm 0.04$ & $1.61 \pm 0.08$ & $1.35 \pm 0.09$ & $1.58 \pm 0.05$ \\
\hline
\end{tabular}

Values are means \pm standard deviations ( $\mathrm{n}=3$ except for diet $1 \mathrm{n}=2$ ). Values in the same row with different superscripts are significantly different $(\mathrm{P}<0.05)$.

${ }^{1} \mathrm{IBW}=$ initial body weight.

${ }^{2} \mathrm{WG}=$ weight gain.

${ }^{3}$ SGR, specific growth rate $=100 \times((\ln$ FBW $-\ln$ IBW $) / 84$ days $)$.

${ }^{4} \mathrm{FE}$, feed efficiency = wet weight gain/dry feed intake.

${ }^{5}$ PER, protein efficiency ratio= wet weight gain/crude protein intake. 
Table 4 : Whole body composition (\% of wet weight basis), hepatosomatic (HSI) and viscerosomatic index (VSI), nutrient and energy retention (\% of intake) in turbot.

\begin{tabular}{|c|c|c|c|c|c|}
\hline & \multicolumn{5}{|c|}{ Experimental diets } \\
\hline & initial & 10 & 15 & 20 & 25 \\
\hline Moisture, \% & 74.7 & $74.5 \pm 0.6$ & $75.5 \pm 0.5$ & $75.0 \pm 0.2$ & $74.7 \pm 0.4$ \\
\hline Ash, \% & 3.6 & $3.9 \pm 0.1$ & $3.8 \pm 0.1$ & $3.9 \pm 0.1$ & $3.8 \pm 0.1$ \\
\hline Protein, \% & 17.3 & $17.4 \pm 0.5$ & $17.2 \pm 0.1$ & $17.4 \pm 0.1$ & $16.9 \pm 0.1$ \\
\hline Fat, \% & 4.2 & $3.0 \pm 0.1^{\mathrm{a}}$ & $3.6 \pm 0.5^{\mathrm{ab}}$ & $3.8 \pm 0.3^{\mathrm{ab}}$ & $4.8 \pm 0.4^{\mathrm{b}}$ \\
\hline Energy (kJ/g) & 5.6 & $5.1 \pm 0.2$ & $5.3 \pm 0.2$ & $5.4 \pm 0.1$ & $5.7 \pm 0.2$ \\
\hline HSI, \% & 1.6 & $1.5 \pm 0.1$ & $1.5 \pm 0.1$ & $1.4 \pm 0.1$ & $1.4 \pm 0.1$ \\
\hline VSI, \% & 2.9 & $2.5 \pm 0.1$ & $2.5 \pm 0.1$ & $2.7 \pm 0.1$ & $2.7 \pm 0.1$ \\
\hline \multicolumn{6}{|l|}{ Retention } \\
\hline Protein & - & $29.6 \pm 4.1$ & $27.6 \pm 2.4$ & $24.6 \pm 1.2$ & $24.3 \pm 0.4$ \\
\hline Energy & - & $17.5 \pm 3.6$ & $18.2 \pm 3.9$ & $15.6 \pm 2.9$ & $23.3 \pm 3.9$ \\
\hline
\end{tabular}

Values are means \pm standard deviations ( $\mathrm{n}=3$ except for diet $1 \mathrm{n}=2$ ). Values in the same row with different superscripts are significantly different $(\mathrm{P}<0.05)$. 
Table 5 : Fat content of liver, viscera, dorsal and ventral muscle and skin in turbot (\% wet weight basis).

\begin{tabular}{|c|c|c|c|c|}
\hline \multirow[b]{3}{*}{ Liver } & \multicolumn{4}{|c|}{ Experimental diets } \\
\hline & 10 & 15 & 20 & 25 \\
\hline & \multirow[b]{2}{*}{$65.7 \pm 1.7^{\mathrm{b}}$} & \multirow[b]{2}{*}{$64.0 \pm 1.5^{\mathrm{ab}}$} & \multirow[b]{2}{*}{$60.1 \pm 1.4^{\mathrm{a}}$} & \multirow[b]{2}{*}{$67.0 \pm 1.3^{\mathrm{b}}$} \\
\hline Moisture & & & & \\
\hline Fat & $13.8 \pm 1.9^{b}$ & $15.9 \pm 1.0^{\mathrm{b}}$ & $21.1 \pm 1.8^{\mathrm{a}}$ & $12.3 \pm 1.2^{\mathrm{b}}$ \\
\hline \multicolumn{5}{|l|}{ Viscera } \\
\hline Moisture & $83.7 \pm 0.3^{b}$ & $83.0 \pm 0.2^{\mathrm{ab}}$ & $83.9 \pm 0.2^{\mathrm{b}}$ & $82.7 \pm 0.4^{\mathrm{a}}$ \\
\hline Fat & $1.9 \pm 0.1^{\mathrm{ab}}$ & $2.0 \pm 0.1^{\mathrm{ab}}$ & $1.6 \pm 0.1^{b}$ & $2.2 \pm 0.1^{\mathrm{a}}$ \\
\hline \multicolumn{5}{|c|}{ Dorsal muscle } \\
\hline Moisture & $78.9 \pm 0.7$ & $78.5 \pm 0.2$ & $78.4 \pm 1.3$ & $78.7 \pm 0.2$ \\
\hline Fat & $1.0 \pm 0.1$ & $1.1 \pm 0.1$ & $1.2 \pm 0.1$ & $1.3 \pm 0.1$ \\
\hline \multicolumn{5}{|c|}{ Dorsal skin } \\
\hline Moisture & $74.8 \pm 1.3$ & $75.8 \pm 0.4$ & $75.6 \pm 0.7$ & $76.1 \pm 0.6$ \\
\hline Fat & $4.5 \pm 1.1$ & $3.7 \pm 0.5$ & $3.8 \pm 0.8$ & $4.1 \pm 0.3$ \\
\hline \multicolumn{5}{|c|}{ Ventral muscle } \\
\hline Moisture & $78.6 \pm 0.8$ & $78.0 \pm 0.2$ & $78.0 \pm 0.4$ & $78.1 \pm 0.3$ \\
\hline Fat & $1.6 \pm 0.3$ & $1.6 \pm 0.1$ & $1.7 \pm 0.3$ & $1.8 \pm 0.1$ \\
\hline \multicolumn{5}{|c|}{ Ventral skin } \\
\hline Moisture & $74.7 \pm 1.4$ & $75.5 \pm 0.4$ & $74.6 \pm 0.7$ & $75.9 \pm 0.5$ \\
\hline Fat & $4.7 \pm 1.4$ & $3.3 \pm 0.5$ & $4.4 \pm 1.1$ & $4.2 \pm 0.3$ \\
\hline
\end{tabular}

Values are means \pm standard deviations $(\mathrm{n}=6)$. Values in the same row with different superscripts are significantly different $(\mathrm{P}<0.05)$. 
Table 6 : Effects of experimental diets on hepatic lipogenic enzyme activities.

\begin{tabular}{|c|c|c|c|c|}
\hline \multirow[b]{3}{*}{$\begin{array}{l}\text { Glucose- } 6 \text { phosphat } \\
\text { dehydrogenase }\end{array}$} & \multicolumn{4}{|c|}{ Experimental diets } \\
\hline & 10 & 15 & 20 & 25 \\
\hline & & & & \\
\hline IU/ g liver & $7.03 \pm 0.62^{\mathrm{b}}$ & $9.92 \pm 0.90^{\mathrm{a}}$ & $7.57 \pm 0.75^{\mathrm{ab}}$ & $8.04 \pm 0.40^{\mathrm{ab}}$ \\
\hline IU/mg protein & $0.22 \pm 0.02^{b}$ & $0.34 \pm 0.02^{\mathrm{a}}$ & $0.23 \pm 0.02^{b}$ & $0.27 \pm 0.02^{\mathrm{b}}$ \\
\hline Malic enzyme & & & & \\
\hline IU/g liver & $1.15 \pm 0.10$ & $0.93 \pm 0.18$ & $0.79 \pm 0.15$ & $0.89 \pm 0.05$ \\
\hline IU/mg protein & $0.05 \pm 0.00$ & $0.04 \pm 0.01$ & $0.03 \pm 0.00$ & $0.04 \pm 0.01$ \\
\hline Acetyl-CoA carboxyl & & & & \\
\hline mIU/g liver & $16.26 \pm 1.48$ & $13.32 \pm 2.19$ & $16.70 \pm 1.87$ & $14.11 \pm 1.61$ \\
\hline mIU/mg protein & $0.36 \pm 0.04$ & $0.31 \pm 0.08$ & $0.43 \pm 0.05$ & $0.36 \pm 0.04$ \\
\hline
\end{tabular}

Values are means \pm standard deviations $(\mathrm{n}=6)$. Values in the same row with different superscripts are significantly different $(\mathrm{P}<0.05)$. 
Table 7 : Sensory analyses of dorsal fillets of turbot

\begin{tabular}{|c|c|c|c|c|c|c|}
\hline & \multirow[b]{2}{*}{ Attributes } & \multicolumn{4}{|c|}{ diets } & \multirow[b]{2}{*}{ ANOVA } \\
\hline & & 10 & 15 & 20 & 25 & \\
\hline \multirow{5}{*}{ ODOUR } & intensity & 5.23 & 4.86 & 5.04 & 4.66 & $\mathrm{p}=0.61$ \\
\hline & potatoes & 2.68 & 3.21 & 2.36 & 2.35 & $\mathrm{p}=0.37$ \\
\hline & fat fish & 2.25 & 1.95 & 2.16 & 2.20 & $\mathrm{p}=0.90$ \\
\hline & marine-iodine & 2.35 & 1.74 & 2.41 & 2.06 & $\mathrm{p}=0.50$ \\
\hline & milky & 1.96 & 2.36 & 2.41 & 2.58 & $\mathrm{p}=0.55$ \\
\hline \multirow{2}{*}{ ASPECT } & whiteness & $3.38^{\mathrm{a}}$ & $4.29^{\mathrm{a}}$ & $4.98^{b}$ & $5.17^{b}$ & $\mathrm{p}=0.018$ \\
\hline & fatness & 3.18 & 3.14 & 2.39 & 2.97 & $\mathrm{p}=0.28$ \\
\hline \multirow{6}{*}{ FLAVOUR } & intensity & 4.64 & 4.47 & 4.71 & 4.27 & $\mathrm{p}=0.74$ \\
\hline & fatty fish & 2.49 & 1.98 & 1.77 & 1.88 & $\mathrm{p}=0.19$ \\
\hline & marine & 3.51 & 2.80 & 3.22 & 2.95 & $\mathrm{p}=0.38$ \\
\hline & sweet & 1.41 & 1.08 & 1.49 & 1.53 & $\mathrm{p}=0.54$ \\
\hline & acid & 0.46 & 0.51 & 0.55 & 0.25 & $\mathrm{p}=0.36$ \\
\hline & bitter aftertaste & 0.79 & 0.74 & 0.76 & 0.71 & $\mathrm{p}=0.98$ \\
\hline & hardness & 5.01 & 4.86 & 5.16 & 4.78 & $\mathrm{p}=0.87$ \\
\hline TEXTURE & elasticity & 3.33 & 3.34 & 3.35 & 3.06 & $\mathrm{p}=0.94$ \\
\hline IN & moisture & 4.25 & 4.88 & 3.68 & 4.45 & $\mathrm{p}=0.19$ \\
\hline \multirow[t]{3}{*}{ MOUTH } & fat & 3.01 & 2.34 & 3.25 & 2.72 & $\mathrm{p}=0.15$ \\
\hline & exudation & $3.79^{\mathrm{a}}$ & $3.64^{\mathrm{a}}$ & $2.58^{\mathrm{b}}$ & $3.12^{b}$ & $\mathrm{p}=0.02$ \\
\hline & sticky & 2.41 & 2.28 & 1.87 & 2.05 & $p=0.69$ \\
\hline
\end{tabular}

Values in the same row with different superscripts are significantly different $(\mathrm{P}<0.05)$ 
Table 8 : Sensory analyses of ventral fillets of turbot

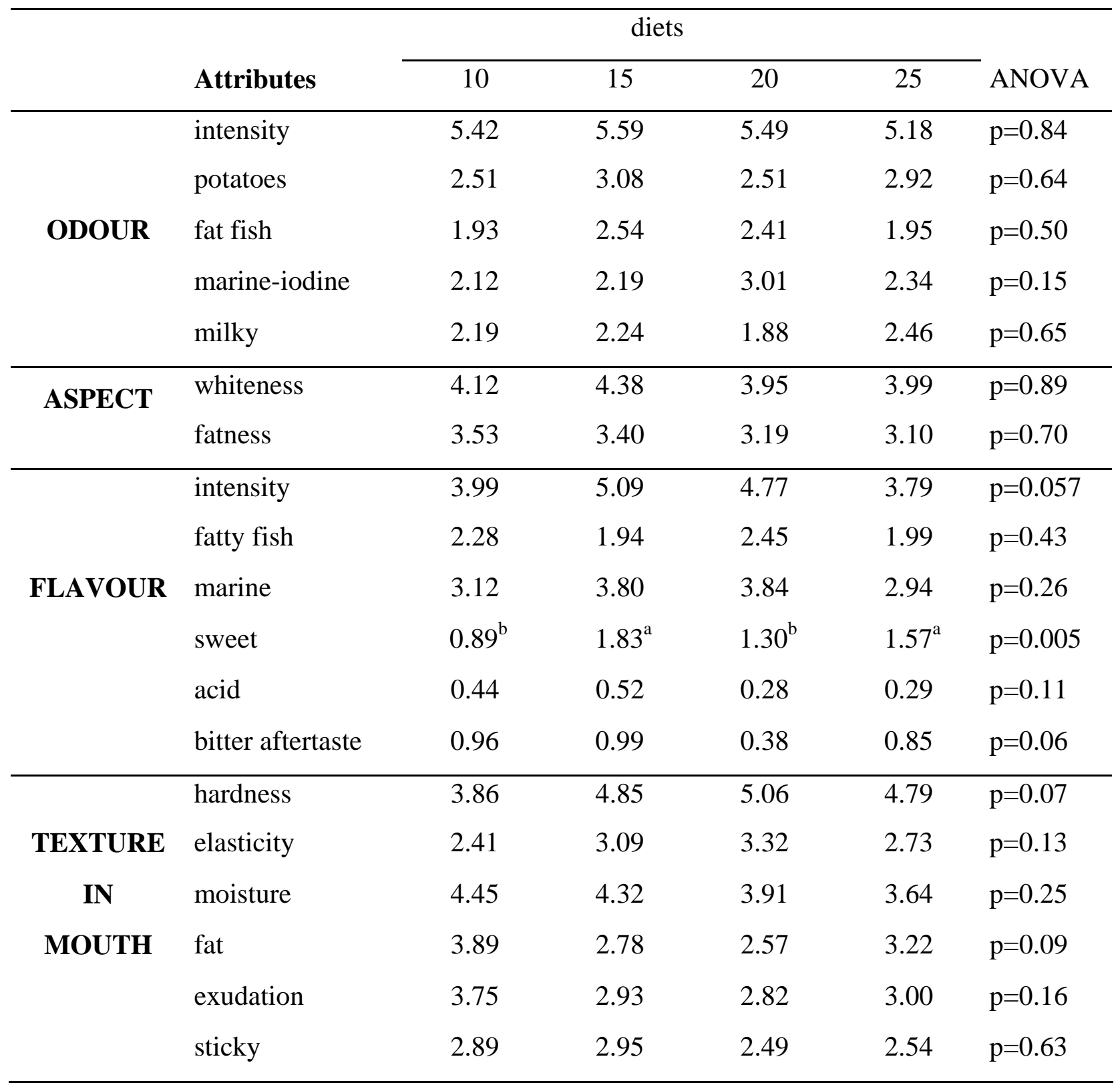

Values in the same row with different superscripts are significantly different $(\mathrm{P}<0.05)$ 
Table 9 : Gutted and fillet yield in turbot and instrumental quality analyses of raw and cooked fillets of turbot fed diets with different fat levels.

\begin{tabular}{|c|c|c|c|c|}
\hline & \multicolumn{4}{|c|}{ Experimental diets } \\
\hline & 10 & 15 & 20 & 25 \\
\hline \multicolumn{5}{|l|}{ Yields } \\
\hline Gutted yield $^{1}$ & $0.96 \pm 0.00$ & $0.96 \pm 0.00$ & $0.96 \pm 0.00$ & $0.96 \pm 0.00$ \\
\hline Fillet yield ${ }^{2}$ & $0.27 \pm 0.01$ & $0.26 \pm 0.01$ & $0.26 \pm 0.01$ & $0.27 \pm 0.01$ \\
\hline \multicolumn{5}{|l|}{ Raw fillet } \\
\hline $\mathrm{pH}$ & $6.48 \pm 0.03$ & $6.45 \pm 0.02$ & $6.49 \pm 0.03$ & $6.52 \pm 0.03$ \\
\hline $\mathrm{L}^{*}$ & $52.00 \pm 0.35^{\mathrm{a}}$ & $50.00 \pm 0.42^{\mathrm{b}}$ & $50.75 \pm 0.49^{b}$ & $50.26 \pm 0.43^{b}$ \\
\hline$A^{*}$ & $-2.50 \pm 0.19$ & $-1.96 \pm 0.19$ & $-1.93 \pm 0.20$ & $-1.77 \pm 0.26$ \\
\hline $\mathrm{B}^{*}$ & $1.63 \pm 0.31$ & $0.84 \pm 0.31$ & $1.98 \pm 0.63$ & $2.49 \pm 0.66$ \\
\hline Maximal force (N/g) & $66.61 \pm 5.48$ & $59.00 \pm 2.68$ & $70.43 \pm 5.88$ & $70.02 \pm 8.54$ \\
\hline Work (mJ/g) & $305.16 \pm 16.79$ & $320.02 \pm 13.93$ & $329.01 \pm 21.36$ & $339.83 \pm 31.67$ \\
\hline Slide Force (N/g) & $5.10 \pm 0.35$ & $4.68 \pm 0.38$ & $4.65 \pm 0.35$ & $5.19 \pm 0.42$ \\
\hline \multicolumn{5}{|l|}{ Cooked fillet } \\
\hline $\mathrm{pH}$ & $6.61 \pm 0.03^{\mathrm{ab}}$ & $6.66 \pm 0.03^{b}$ & $6.55 \pm 0.03^{\mathrm{a}}$ & $6.69 \pm 0.04^{\mathrm{b}}$ \\
\hline $\mathrm{L}^{*}$ & $76.89 \pm 0.40^{\mathrm{a}}$ & $77.01 \pm 0.54^{\mathrm{a}}$ & $76.19 \pm 0.52^{\mathrm{ab}}$ & $74.92 \pm 0.78^{b}$ \\
\hline$a^{*}$ & $-1.38 \pm 0.23$ & $-1.05 \pm 0.20$ & $-0.84 \pm 0.15$ & $-0.67 \pm 0.21$ \\
\hline$b^{*}$ & $9.40 \pm 0.41^{\mathrm{a}}$ & $9.25 \pm 0.31^{\mathrm{a}}$ & $9.96 \pm 0.28^{\mathrm{ab}}$ & $10.86 \pm 0.45^{b}$ \\
\hline Maximal force (N/g) & $15.25 \pm 0.70$ & $16.05 \pm 0.91$ & $15.45 \pm 0.96$ & $14.34 \pm 0.80$ \\
\hline Work (mJ/g) & $72.22 \pm 3.05$ & $85.01 \pm 3.50$ & $80.46 \pm 4.41$ & $73.90 \pm 4.01$ \\
\hline Slide Force (N/g) & $6.26 \pm 0.29$ & $7.28 \pm 0.37$ & $6.11 \pm 0.42$ & $6.15 \pm 0.34$ \\
\hline
\end{tabular}

Values are means \pm standard deviations $(n=8)$. Values in the same row with different superscripts are significantly different $(\mathrm{P}<0.05)$.

${ }^{1}$ Gutted yield = carcass weight/fish weight

2 fillet yield $=$ fillet weight/fish weight 
Legend to figures

Figure 1

Effects of dietary fat levels on daily whole body protein and lipid gain of turbot.

Figure 2

Effect of different fat levels in diets on plasma cholesterol and triglyceride concentrations in turbot. 


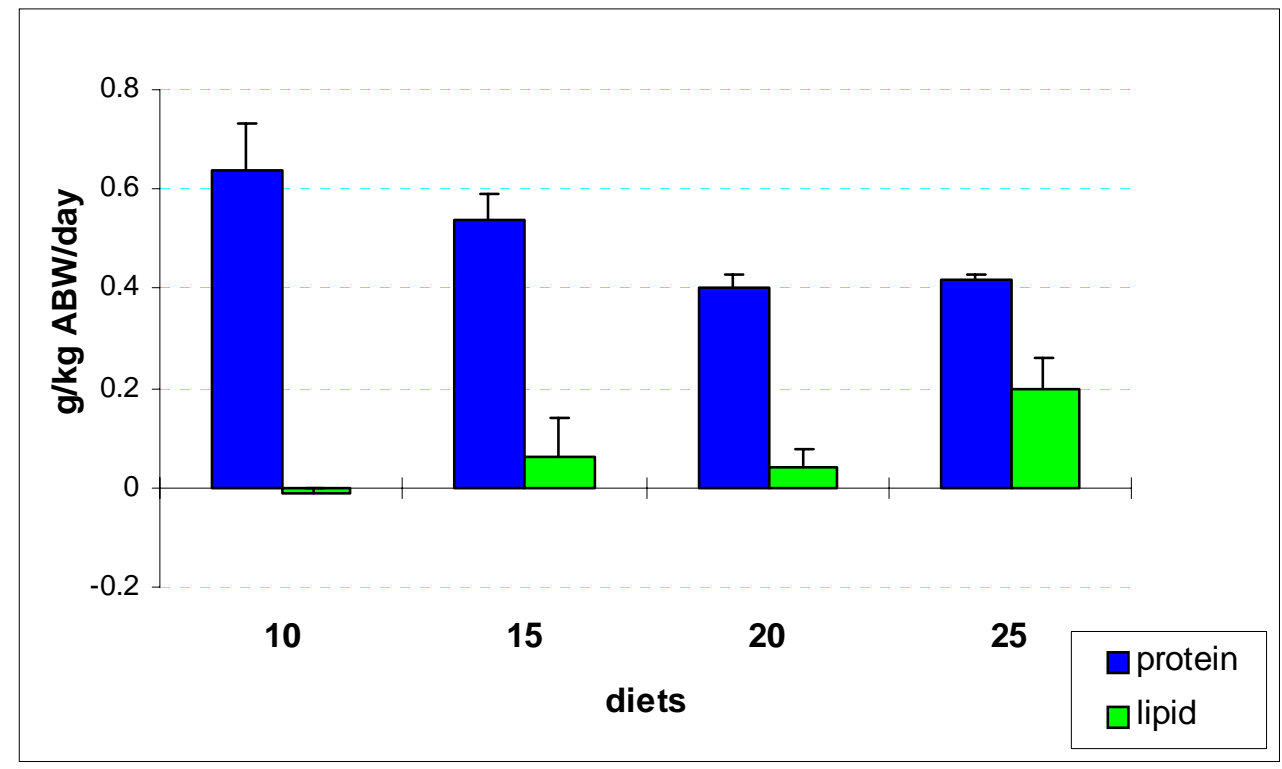

Figure 1 : Effects of dietary fat levels on daily whole body protein and lipid gain of turbot.

Errors bars are standard deviations.

ABW : Average body weight : (IBW + FBW)/2 


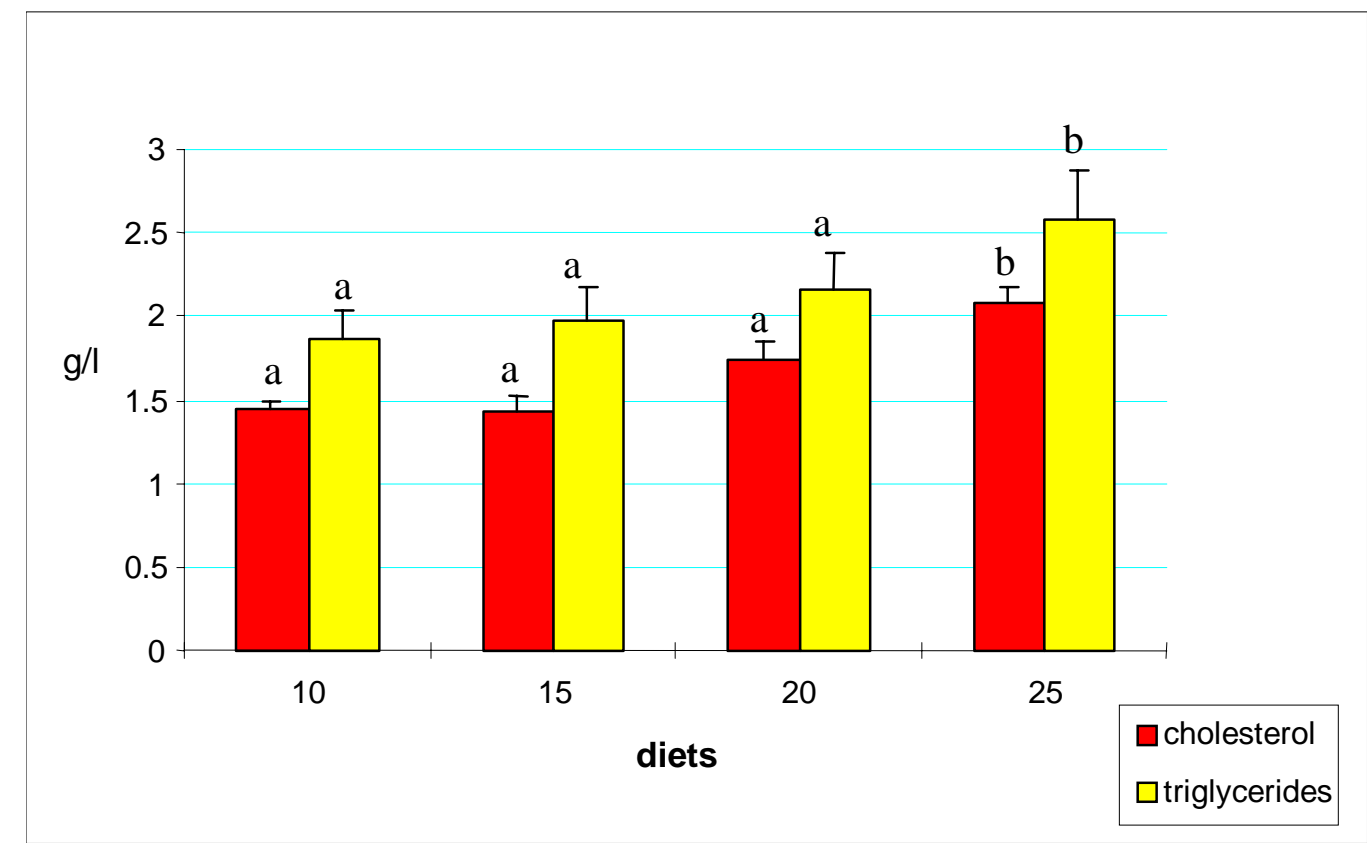

Figure 2 : Effect of different fat levels in diets on plasma cholesterol and triglyceride concentrations in turbot.

Errors bars are standard deviations.

Different superscripts are significantly different $(\mathrm{P}<0.05)$. 